Article

\title{
The Effect of COVID-19 in University Tutoring Models
}

\author{
David Pérez-Jorge 1,*(1), María del Carmen Rodríguez-Jiménez ${ }^{1}$, Eva Ariño-Mateo ${ }^{2}$ \\ and Fernando Barragán-Medero ${ }^{1}$ \\ 1 Department of Didactic and Educational Research, University of La Laguna, \\ 38200 San Cristóbal de La Laguna, Spain; mcrojime@ull.edu.es (M.d.C.R.-J.); fbarraga@ull.edu.es (F.B.-M.) \\ 2 Department of Psychology, LIGS University, 17000 Praha, Czechia; eva.mateo@ligsuniversity.com \\ * Correspondence: dpjorge@ull.edu.es; Tel.: +34-618-812-433
}

Received: 27 September 2020; Accepted: 14 October 2020; Published: 18 October 2020

check for updates

\begin{abstract}
This research is part of the Educational Research Project developed at the University of La Laguna during the academic year 2019-2020, which included the period of confinement by COVID-19. The study was carried out with a sample of 193 student teachers in Early Childhood Education, Primary and four master's degree programs offered by the Faculty of Education of the University of La Laguna. Four tutoring models were analyzed; in person, by e-mail, using virtual tutoring (Hangout/Google Meet) and WhatsApp. The results confirm the need to enhance synchronous models, as the most effective models for the development of the process of academic orientation and support for students, compared to asynchronous models. These delay the processes of academic decision-making and have a significant effect on them, as well as the pace of study and the motivation of the students, hindering the processes of learning, adaptation and fulfilment.
\end{abstract}

Keywords: tutoring; COVID-19; university; e-learning; communication

\section{Introduction}

The tutor/student relationship is marked by a high level and degree of collaboration, communication, sincerity, trust, security, closeness, identification, empathy and mutual acceptance, which is achieved in the sequence of interactivity between peers [1,2]. The need to create adequate channels of communication for the tutoring and advice for students throughout their training process requires the development of an effective tutoring model that allows for improvement in the student's academic and personal adaptation to university. This situation has become particularly relevant during the year 2020, given the confinement imposed by the COVID-19 pandemic. The appropriate use of alternative models of tutoring (e-tutoring) has allowed the improvement of the processes of adaptation to the university context, which is especially relevant in situations of physical nonattendance. The processes of guidance, advice and support in training processes are key to the students' progress and are fundamental to the improvement of motivation and the prevention of drop-out. Situations such as the one we have experienced have caused us to rethink the models of teaching, especially those of tutoring and counseling students. This has led to a careful reconsideration of the role and commitment of teachers in relation to tutoring models. Regaining social contact through a "virtual synchronous relationship" is an alternative to physical presence, which can mark the future of academic relationships. We do not know for how long or when situations such as that experienced during the confinement caused by COVID-19 will be repeated again, but what we can sense intuitively is that it will be necessary to rehearse alternative models of guidance, advice and support for students. The reality is uncertain and very volatile, and demands responsibility and commitment, both from the university faculty and the students. 
It is possible to respond to this challenge by modifying the time periods and tools used for the development of the advisory and mentoring processes. Thus, this work presents the results of an experience that has tried to compensate for the effects of the transition from a face-to-face teaching model to a virtual teaching model. The research was developed at the University of La Laguna, which has gone from an educational model equipped with $80 \%$ face-to-face tutoring and $20 \%$ virtual to a model of $100 \%$ virtual teaching and tutoring.

\subsection{Conceptual Framework of Study}

The tutoring system, in the context of Higher Education, has been deemed to be a relevant and key aspect of the university training model, which is focused mainly on the processes of support, guidance and advice for the progress and academic success of the students. This new concept of the Higher Education model requires the adaptation of the roles of its protagonists. It requires changes in the mindset of current and trainee teachers, with a redefinition of their roles. The success and progress of the students will largely depend on the involvement and commitment of teachers. Teachers are no longer simply a source of knowledge; in their new role as advisor and mentor, they become a tutor who accompanies students in their progress and transit through the university.

Since the beginning and subsequent implementation of the European Higher Education Area (EEES), there has been talk of change and reorientation in the university teaching model and the characteristics of the new teacher who is committed to mentoring and advising students. More literature data as defined this type of teacher as "flexible, open to change, able to analyze their teaching, critical of himself, with mastery of cognitive and relational skills" [3] (p. 2). The disconnection between the university and social and economic contexts required urgent intervention in Higher Education models to ensure a more competitive and higher quality common education system [4]. Despite this, [5,6] expressed pessimism regarding the implementation of the EEES in university classrooms. Also, [7-13] state that university tutoring is a student right and an identifying element of the quality of the 21st century university.

The importance of tutoring has increased since it not only allows the personalization of teaching, but also the integral development of students, the prevention of drop-out and training in cross curricular skills [10]. It is necessary to reflect on the content of this process of student guidance at different educational stages. Reference [4] points to the need for a complete model of university tutoring, focused on ways to "to promote the integral development of students, to be part of university culture, to be integrated into the curriculum, adapted to the specific needs of students and the center from which it develops and to be enhanced by institutional policy" (p. 192).

The task of guidance and support should not be by appointment, isolated or encompass only the period of student incorporation into the university, but rather should cover each and every academic course. Students need support, advice and guidance throughout their academic career to respond successfully to such important issues as the diversification of the curriculum of undergraduate studies, postgraduate and doctoral programs or complementary training (extension courses, self-configured courses, conferences, seminars or workshops). These types of decisions increase the training development of students as long as they are consistent with the formative profile of the students. That is why these decision-making processes require adequate reflection, advice and support, in order to reduce uncertainty and increase knowledge in relation to their academic and professional future.

University tutoring is increasingly necessary to more successfully address the diverse needs that arise as a result of the increasingly heterogeneous realities of the students. It is essential to adapt urgently to these realities and to the rhythms and speed of change that are happening in training, in social and professional areas. In order to achieve these methods, they need to be adapted for the use of media and technology, which will improve the process of tutoring. 


\subsection{Adaptation to the University Context}

The entrance into the European Higher Education Area was an important recognition and impetus for the tutorial function in university contexts and the role and part played by academic tutors in this context. However, significant weaknesses were identified in relation to the design, organization and operation of the programs and orientation plans developed by Spanish universities $[3,14,15]$. These authors stated that the models of university tutoring had weaknesses both in the tasks of planning, coordination and motivation, as well as in those of training and involvement of teachers and students.

Given the evidence of weaknesses in "normal" situations, large deficiencies and weaknesses can be hypothesized in the current scenario. That is why this research paper proposes how this new confinement scenario (due to COVID-19) has influenced the development of the academic guidance and mentoring processes.

The use of emerging synchronous virtual tutoring models in universities results in academic improvement, specifically in relation to the decrease in failure and premature abandonment rates. That is why adequate support is needed for students, in which they are offered knowledge in relation to the structure and university studies, and student rights and duties. In addition, the offer of training and cultural activities in which students can be integrated can be key to a more effective adaptation to the formative context [4].

In this research, the processes of adaptation and satisfaction of the participating students were analyzed regarding the support and advice that was developed during the 2019-2020 academic year, which included moments of face-to-face tutoring and moments of total virtual tutoring, as a consequence of the confinement decreed by the government of Spain.

The effect of the change in models arising from the situation of the COVID-19 pandemic was analyzed. University tutoring models became more important than ever, especially those related to the use of new technologies (e-mail, Hangout/Google Meet and WhatsApp). These tutoring models were more important during the COVID-19 period because of the effects that confinement has had in relation to satisfaction with processes of support, guidance, and student advice.

"Tutoring should accompany students in the development of styles and strategies of learning, organization of study, approach of the different subjects and subjects, realization of internships, etc." [4] (p. 195) but must also conform to individual characteristics and formative contexts. Based on this fact, and the context and reality left by COVID-19, the teaching of students requires changes by both teachers and students.

Several studies [16-19] state that it is necessary to create specific educational programs for each grade, which guarantee success in teaching and in the transition of students to each of the grades. The periods of transition of students, either to the university or within the undergraduate and graduate studies themselves, have been identified as highly stressful periods due to the lack of support received by the students [20], to organizational, academic and professional challenges [20,21] and expectations of immediate optimal performance [22,23]. There is a link between the expected lack of support and the stress expressed by the students. In addition, other stress-causing variables have been identified in students, such as difficulties in communication, academic isolation, workload and lack of personal and professional development [23,24].

The reality of the confinement and the speed with which COVID-19 spread left our students without reference, without an educational model that guaranteed academic success, without communication patterns through an effective synchronous model and without clear patterns to continue their education.

\subsection{Technological Tools and Resources for Advice and Synchronous Support as Key to the Transition to the New Education}

The use of technological tools and resources for support, advice and guidance in university contexts is nothing new [25-27], especially in the field of learning, development and evaluation of skills. Forums, web repositories, SMS, e-mail, are tools and resources to support learning that have tried to 
complete the student's training processes in a virtual manner, [28] notes that the new training scenarios require the development of professional skills by the teachers, adapted to the new technological times and means. Physical presence is no longer the only way to implement skills and abilities related to organization and planning, mentoring, student orientation, training process, group leadership, motivation etc. However, there are a variety of technological tools and resources available in the new training spaces that could help achievement and development.

Benefits have been shown in relation to the use of the Forum [29-32], the formative possibilities of Hangout [33-36] and the use of WhatsApp for the improvement of training processes [12,37-41], and above all, the improvement of the educational possibilities of emerging technological tools and resources such as those referred to.

On the other hand, it has been shown that the use of a mobile phone to access various activities on Moodle is not as an effective learning tool due to the limitations of mobile access to the students on usability and reliability [42,43].

More literature data point out that the tutorial process involves "the establishment of communication between teachers and students, on issues related to the shaping of scientific dominance and the establishment of favorable attitudes towards the search for and pleasure in scientific knowledge" [28] (p. 3) but can also be seen as a unique opportunity, especially in contexts with limited support mechanisms [44,45].

Synchronous online teaching and the processes of tutoring and student support require a "set of new and extended skills" [46] (p. 114) that go beyond the simple treatment and clarification of tasks and content of the subjects. Teachers should provide students with timely feedback, including support, guidance and advice through current means such as WhatsApp, or Google apps such as Meet or Hangouts. These provide types of online communication, guaranteeing a quality contact and a "virtual closeness", which breaks with the social estrangement implemented worldwide. New technologies and web applications could be the alternative plan for face-to-face; however, it is necessary to address potential problems, such as the traffic overload of the education platforms, or the saturation of virtual systems due to the "forced migration" of face-to-face to virtual forms, as has been the case of the University of La Laguna.

In terms of the importance of working methods, which bring the students to prominence, tutoring has been put forward as one of the most important practices of the university faculty. This has now reached the point where it is increasingly difficult to separate out the formative aspect of teaching in tutorial. The use of the tutorial has long been conceived as above all a face-to-face experience.

More literature data state that the main educational problem arising from the COVID-19 virus outbreak has been social isolation [47]. There is evidence that socialization is a fundamental aspect of cognition [48]. From the perspective of social learning theory, complex skills are developed through socialization and interaction [49]. However, the situation of preventative social isolation and the return to "the new normal" will be a major limitation on the return to schools. The processes of interaction and relationship between colleagues will be conditioned by distance, and partial solutions such as screens or so-called bubbles (classrooms for small group interaction) will be insufficient to return the interaction and contact needed for learning. More literature data have pointed out that the integration of information and communication technologies (ICT) into schools should mean the transformation of traditional learning environments and the creation of new teaching and learning models based on the interconnection and intercommunication of virtual or online environments [50]. Commitment and interaction with students will depend to a large extent on the skills and abilities in ICT of teachers and the so-called soft skills [51].

There are many questions and doubts arising from the impact that the pandemic has had on teaching, and in particular, on a university education based on traditional face-to-face formative contexts. How is out-student counseling, support and guidance carried out in virtual contexts? Are we ready to provide quality online teaching? What about students who need support to learn online? More literature data have pointed out that the integration of ICT into schools should mean the 
transformation of traditional learning environments and the creation of new teaching and learning models based on the interconnection and intercommunication of virtual or online environments [50]. Commitment and interaction with students will depend to a large extent on the skills and abilities in information and communication technologies (ICT) of teachers and the so-called soft skills [51-53]. The experience gained during COVID-19 can be a good opportunity for the renewal of the educational model, the development of teaching and learning in the university context, an opportunity to move beyond traditional asynchronous models [54]. However, there are training gaps concerning motivation and communication strategies. The weaknesses of the virtual synchronous model, in relation to the processes of counseling, advice and support for students, remain unsolved to this day.

At the core of this study are some fundamental principles of orientation intervention in Higher Education contexts. Such principles are based on prevention-through continuous clarification and advice for the student, and active learning - as a teaching-learning strategy whose design and implementation is focused on promoting student participation, reflection and continuous training through the process of communication and permanent interaction offered by the different models of tutoring, especially those with less tradition of use. These have become the methods which have been most widely used by students and teachers during the period of confinement.

In this point, we ask ourselves, are the university tutoring models carried out at the University of La Laguna just as effective? Could some tutoring models report greater satisfaction and success in the academic guidance and tutoring processes?

\section{Materials and Methods}

\subsection{Objectives of the Study}

The objective of this study is to analyse the effects that different tutoring models have on the processes of adaptation and the level of satisfaction student of students from the University of La Laguna, during the 2019-2020 academic year.

\subsection{Participants}

The valid sample of 193 students represented $58.5 \%$ of the students of the infant education teacher qualifications ( $N=32$ out of a total 118 students; $27.2 \%$ ); of primary education ( $N=77$ out of a total of 112 students; $68.8 \%)$ and ( $N=60$ out of a total of $102 ;(58.8 \%)$ of students of four master's degree programs offered by the Faculty of Education of the University of La Laguna). Distribution is detailed in Table 1.

Table 1. Characteristics and distribution of the sample.

\begin{tabular}{cc}
\hline Characteristics & N $^{\mathbf{o}}$ of Subjects \\
\hline Gender & Male: $22(11.4 \%)$ \\
Female: $171(88.6 \%)$ \\
\hline Degree Year & 3rd and 4th: $133(68.9 \%)$ \\
& Postgraduate: $60(31.1 \%)$ \\
\hline Qualification & Infant Teacher: $32(16.6 \%)$ \\
& Primary Teacher: $77(39.9 \%)$ \\
\hline Age Group & Masters student: $84(43.5 \%)$ \\
Average age: 23 years & Within 18 and 22: $92(47.7 \%)$ \\
Minimum: 19 Maximum: 41 & Within 2 and 25: $85(44.0 \%)$ \\
\hline
\end{tabular}

\subsection{Instrument and Techniques}

A questionnaire was created for this study in order to evaluate the level of student satisfaction with the tutoring models used and the effect of the different forms of tutoring (WhatsApp, face-to-face 
tutoring, virtual tutoring and e-mail) on the process of adaptation of the students, at the University of La Laguna, to the COVID-19 confinement situation. The [12,55] tests were taken into account in the preparation of the questionnaire (2018). This was a test specifically designed for this study that tried to collect the opinions of the students as to the uses of the different forms of tutoring in relation to improving university adaptation and satisfaction with tutoring processes. This was a Likert questionnaire with five response levels in which value one indicates the lowest degree of agreement and five indicates the highest degree of agreement.

The instrument, called "Questionnaire on Adaptation to the University Context through Tutoring" (CACUT), was subjected to different content validation tests [56-59], namely:

- Pilot: passed to 10 students of the third and fourth grade, to evaluate the wording of the items in terms of clarity, understanding and adequacy of the response.

- Evaluation of judges: two university professors in the field of orientation rated the items in terms of relevance and adequacy.

The test consisted of a total of 17 items where tutoring modalities were analyzed (e-mail, WhatsApp and virtual tutoring); 4 identification items, 1 item on use and frequency of use of the form of tutoring, 6 items on the adaptability of students to the university context using the different forms of tutoring, 5 focused on the support and advice carried out by the teachers, and 1 on general satisfaction with the different forms of tutoring.

\subsection{Data Analysis}

All the data collected in the questionnaire online respected the anonymity of the person who responded, and held according to the Data Protection Act and respecting the rules thereof (Organic Law 3/2018, of 5 December, Protection of Personal Data and guarantee of digital rights). This research was approved by the Ethical Committee of the University of La Laguna (CEIBA), reference: CEIBA 2020-0411.

Based on the objective set for this study, analyses were performed to (1) check the internal consistency of the test for which the Cronbach alpha coefficient was used, (2) carry out an exploratory descriptive analysis of the questionnaire items and (3) use the Spearman correlation coefficient for correlation study. Analyses were performed through SPSS Statistics 25.

\section{Results}

The reliability analysis of the test used was performed and obtained a Cronbach value of 0.89 . Taking into account the reliability levels proposed by [60], it can be said that, overall, all items reached a fairly high coefficient, which allowed for the instrument to be considered reliable.

As shown in Table 2, the most commonly used forms were e-mail and WhatsApp, with virtual tutoring used the least.

Table 2. Frequency of use of the tutoring model.

\begin{tabular}{ccccc}
\hline & E-Mail & Face-to-Face & $\begin{array}{c}\text { Virtual } \\
\text { (Hangout/Google Meet) }\end{array}$ & WhatsApp \\
\hline Mean & 3.27 & 2.61 & 1.52 & 3.23 \\
\hline Sd & 1.52 & 1.31 & 0.90 & 1.57 \\
\hline
\end{tabular}

The results of the Kolmogorov-Smirnov test of greater than 0.05 allowed us to accept the null hypothesis and admit the assumption of normality of the distribution of the sample.

In relation to the time consumed in each of the tutoring models (see Table 3), it was observed that, in face-to-face and virtual tutoring, the highest frequency of use was less than one hour per week. With respect to e-mail and WhatsApp modalities, a higher frequency of use was observed: between one and three hours in the case of e-mail (30.6\%) and more than three hours for WhatsApp $(31.1 \%)$. 
Students made greater use of WhatsApp (47.7\%) (between one and three hours per week and more than three hours per week).

Table 3. Total time of use for the various tutoring models.

\begin{tabular}{ccccccccc}
\hline & \multicolumn{1}{c}{ E-Mail } & \multicolumn{2}{c}{ Face-to-Face } & \multicolumn{2}{c}{$\begin{array}{c}\text { Virtual } \\
\text { (Hangout/Google Meet) }\end{array}$} & \multicolumn{2}{c}{ WhatsApp } \\
\hline & Fr & $\%$ & Fr & $\%$ & Fr & $\%$ & Fr & $\%$ \\
\hline Less than 1 h per week & 128 & 66.3 & 166 & 86 & 180 & 93.3 & 101 & 52.3 \\
\hline 1-3 h per week & 59 & 30.6 & 24 & 12.4 & 13 & 6.7 & 32 & 16.6 \\
\hline More than 3 h per week & 6 & 3.1 & 3 & 1.6 & 0 & - & 60 & 31.1 \\
\hline Mean & 1.37 & & 1.16 & & 1.07 & & 1.79 \\
\hline Sd & 0.54 & 0.40 & & 0.25 & & 0.89 \\
\hline
\end{tabular}

Concerning the improvement of the process of student adaptation, it was observed that the students responded that tutoring through WhatsApp helped more than the other tutoring models to get to know the university and its resources, to improve the relationship with teachers, methods of study, academic and professional planning, and motivation and interest in study and university inclusion, see Table 4.

Table 4. Improved adaptation process depending on the tutoring model.

\begin{tabular}{ccccccccc}
\hline & \multicolumn{2}{c}{ E-Mail } & \multicolumn{2}{c}{ Face-to-Face } & \multicolumn{2}{c}{$\begin{array}{c}\text { Virtual } \\
\text { (Hangout/Google Meet) }\end{array}$} & Whats App \\
\hline & Mean & Sd & Mean & Sd & Mean & Sd & Mean & Sd \\
\hline $\begin{array}{c}\text { Awareness of } \\
\text { the university } \\
\text { and its resources }\end{array}$ & 2.50 & 1.66 & 2.30 & 1.47 & 1.67 & 1.21 & 2.88 & 1.72 \\
\hline $\begin{array}{c}\text { Relationship } \\
\text { with the teachers }\end{array}$ & 2.56 & 1.68 & 2.69 & 1.73 & 1.99 & 1.38 & 2.83 & 1.52 \\
\hline $\begin{array}{c}\text { Methods of } \\
\text { study }\end{array}$ & 2.19 & 1.57 & 2.50 & 1.69 & 1.97 & 1.32 & 3.24 & 1.46 \\
\hline $\begin{array}{c}\text { Academic and } \\
\text { professional } \\
\text { planning. }\end{array}$ & 2.40 & 1.69 & 2.57 & 1.49 & 2.11 & 1.37 & 2.97 & 1.64 \\
\hline $\begin{array}{c}\text { Motivation to } \\
\text { study }\end{array}$ & 2.22 & 1.56 & 2.35 & 1.55 & 1.95 & 1.28 & 3.08 & 1.74 \\
\hline $\begin{array}{l}\text { Inclusion and } \\
\text { monitoring of } \\
\text { university life }\end{array}$ & 2.37 & 1.77 & 2.21 & 1.70 & 2.12 & 1.42 & 3.05 & 1.69 \\
\hline
\end{tabular}

In relation to the support received from the teachers, the face-to-face and WhatsApp tutoring models were shown as the methods that most satisfied the students (see Table 5). 
Table 5. Satisfaction with the support provided by the teachers.

\begin{tabular}{ccccccccc}
\hline & \multicolumn{2}{c}{ E-Mail } & \multicolumn{2}{c}{ Face-to-Face } & \multicolumn{2}{c}{ Virtual } \\
& Mean & Sd & Mean & Sd & Mean & Sd & Mean & Sd \\
\hline $\begin{array}{c}\text { Interaction with } \\
\text { the teachers }\end{array}$ & 3.19 & 1.48 & 3.50 & 1.37 & 2.80 & 1.36 & 3.28 & 1.87 \\
\hline $\begin{array}{c}\text { Information } \\
\text { received }\end{array}$ & 3.50 & 1.53 & 3.30 & 1.47 & 2.15 & 1.49 & 3.51 & 1.69 \\
\hline $\begin{array}{c}\text { Advice received } \\
\text { Frequency of } \\
\text { response }\end{array}$ & 3.36 & 1.34 & 3.39 & 1.46 & 2.15 & 1.51 & 3.39 & 1.64 \\
\hline $\begin{array}{c}\text { Availability of } \\
\text { the teachers }\end{array}$ & 3.33 & 1.32 & 3.48 & 1.44 & 2.80 & 1.33 & 3.38 & 1.79 \\
\hline
\end{tabular}

In relation to the overall level of satisfaction with the tutoring model, the students expressed the most satisfaction with WhatsApp (see Table 6).

Table 6. General satisfaction with the tutorial style.

\begin{tabular}{|c|c|c|c|c|c|c|c|c|}
\hline & \multicolumn{2}{|c|}{ E-Mail } & \multicolumn{2}{|c|}{ Face-to-Face } & \multicolumn{2}{|c|}{$\begin{array}{c}\text { Virtual } \\
\text { (Hangout/Google Meet) }\end{array}$} & \multicolumn{2}{|c|}{ WhatsApp } \\
\hline & Mean & Sd & Mean & Sd & Mean & Sd & Mean & Sd \\
\hline $\begin{array}{c}\text { General } \\
\text { Satisfaction }\end{array}$ & 3.42 & 1.52 & 3.07 & 1.69 & 2.24 & 1.40 & 3.54 & 1.80 \\
\hline
\end{tabular}

\subsection{Exploring the Relationship by Dimensions and Style of Tutoring}

The Spearman correlation coefficient was used to explore the quantitative relationship between variables, as the sample did not conform to the normal distribution. Frequency of use and improvement of the adaptation process depended on the type of tutoring.

The analysis expresses the relationship between the scores given by students between the frequency of use of the tutoring style (FUT) and the valuation of activities developed in the adaptation process (APA). The FUT variable ranged from one to five, while the APA variable was obtained from the arithmetic means obtained from the six activities described.

The results reflected a significant relationship between FUT and APA (see Table 7).

Table 7. Matrix of correlations between frequency of use of the tutoring style (FUT) and adaptation process (APA).

\begin{tabular}{ccccc}
\hline \multirow{2}{*}{$\begin{array}{c}\text { Process of } \\
\text { Adaptation }\end{array}$} & E-Mail & Face-to-Face & $\begin{array}{c}\text { Firtual } \\
\text { (Hangout/Google Meet) }\end{array}$ & WhatsApp \\
\cline { 2 - 5 } & $0.474^{* *}$ & $0.377^{* *}$ & $0.147^{*}$ & $0.238^{* *}$ \\
\hline E-mail & $0.181^{*}$ & $0.350^{* *}$ & 0.026 & 0.110 \\
\hline Face-to-Face tutorial & 0.105 & 0.085 & $0.232^{* *}$ & $0.154^{*}$ \\
\hline Virtual tutorial & $0.438^{* *}$ & $0.458^{* *}$ & $0.216^{* *}$ & $0.448^{* *}$ \\
\hline WhatsApp & \multicolumn{2}{c}{ Note: $^{* *} p<0.01^{*} p<0.05(N=193)}$.
\end{tabular}

The tutoring model developed through WhatsApp was the one that was the most helpful during the adaptation process. 


\subsection{Frequency of Use and Student Satisfaction Depending on the Style of Tutoring}

The analysis showed a relationship between the frequency of use of the tutoring style (FUT) and the assessment on the satisfaction of support received from the teachers (SAP). The SAP score was obtained from the arithmetic mean of the five support actions described.

The results confirmed a significant relationship between the style of tutoring used and the support received through this style (see Table 8).

Table 8. Matrix of correlation between frequency of use of the tutoring style (FUT) and satisfaction of support received from the teachers (SAP).

\begin{tabular}{ccccc}
\hline \multirow{2}{*}{$\begin{array}{c}\text { Satisfaction with } \\
\text { the Support Process }\end{array}$} & E-Mail & Face-to-Face Tutorial & $\begin{array}{c}\text { Virtual } \\
\text { (Hangout/Google Meet) }\end{array}$ & WhatsApp \\
\cline { 2 - 5 } & $0.406^{* *}$ & $0.230^{* *}$ & 0.024 & $0.275^{* *}$ \\
\hline E-mail & $0.192^{* *}$ & $0.295^{* *}$ & -0.120 & $0.154^{*}$ \\
\hline Face-to-Face tutorial & -0.009 & 0.098 & $0.307^{* *}$ & -0.074 \\
\hline Virtual tutorial & $0.253^{* *}$ & $0.204^{* *}$ & 0.024 & $0.664^{* *}$ \\
\hline WhatsApp & \multicolumn{3}{c}{ Note: ${ }^{* *} p<0.011^{*} p<0.05(N=193)}$.
\end{tabular}

The tutoring model developed through WhatsApp is the one that produced the most student satisfaction in relation to the support provided by teachers.

\subsection{Relationship between the Frequency of Use of the Tutoring Style and the Assessment of the Overall Level of} Satisfaction with Each Style

The results confirmed a trend between the frequency of use of the tutoring style and general satisfaction (SG) according to the same style (see Table 9).

Table 9. Matrix of correlation between frequency of use of the tutoring style (FUT) and general satisfaction (SG).

\begin{tabular}{ccccc}
\hline \multirow{2}{*}{$\begin{array}{c}\text { General Level of } \\
\text { Satisfaction }\end{array}$} & E-mail & Face-to-Face Tutorial & $\begin{array}{c}\text { Virtual } \\
\text { (Hangout/Google Meet) }\end{array}$ & WhatsApp \\
\cline { 2 - 5 } & $0.450^{* *}$ & $0.302^{* *}$ & $0.143^{*}$ & $0.376^{* *}$ \\
\hline E-mail & $0.206^{* *}$ & $0.490^{* *}$ & -0.028 & $0.213^{* *}$ \\
\hline Face-to-Face tutorial & $0.012^{* *}$ & $0.214^{* *}$ & -0.097 \\
Virtual tutorial & -0.051 & $0.321^{* *}$ & $0.153^{*}$ & $0.510^{* *}$ \\
WhatsApp & $0.296^{* *}$ & Note: $^{* *} p<0.01^{*} p<0.05(N=193)$.
\end{tabular}

The tutoring model developed through WhatsApp was the one that produced the most general satisfaction in the students.

\section{Discussion and Conclusions}

COVID-19 has generated changes in the current educational model, specifically, in the communication processes between teachers and students [28]. The communication between the two parties has been transformed from face-to-face to non-face-to-face (the latter may be synchronous or asynchronous), which has required the use of new technologies. That is why the proper use of technological tools and resources is one of the professional skills required in the educational model prevailing during COVID-19 for the implementation of skills and abilities related to organization and planning, mentoring, student orientation, training process, group leadership, motivation etc. [28]. Teachers have been forced to transform their way of advising and guiding students, probably without sufficient tools due to a lack of training and qualification for it. The COVID-19 pandemic has caught 
both students and teachers by surprise, who have been forced to adjust and adapt the counseling and tutoring processes in an attempt to avoid situations of failure and abandonment. The support, advice and guidance processes carried out during the 2019-2020 academic year have shown the weaknesses of some tutoring models compared to others, and have allowed for an assessment of the strengths and weaknesses of each and every one of the tutoring models.

In accordance with [12], our results show the importance of using alternative teaching-learning models without forgetting the tutoring and support processes for students. The adaptation processes that occurred have shown the difficulties of assuming the virtual synchronous model by the universities, which from our point of view has endangered the permanence-nonabandonment-of the students and deterioration in performance.

The link between the current educational model and technological tools and resources has highlighted the wide variety of technological means available to carry out different online teaching processes [44]. In addition, it has been shown that synchronous online teaching and the processes of tutoring and support for students require, in addition to skills in new technologies, new and extended skills [44] that go beyond the simple treatment and clarification of tasks and content of the subjects as stated by $[7-10,12,13]$.

A large number of technological tools and resources are available to teachers. Forum, Hangout and WhatsApp, are part of the most used technological tools and resources and there is scientific evidence around their educational benefits $[12,29,34]$. The situations of evaluation of the educational effects of these tools are becoming more frequent; in this work we do not discuss the preference or improvement of the results of some over others [42,43], but we do assess the beneficial effect of synchronous models, especially in situations in which those students demand guidance and advice. With the results of our study, we shed light on the dilemma of the adequacy effect, in temporal terms, of the information and benefits on the appropriate decision-making processes, which make the guidance and tutoring processes fundamental for the success of the students. It is necessary to adapt training contexts through the appropriate and effective use of resources and technological tools [4].

The evidence provided in this research, in relation to the proposed objective for it, allows us to affirm that the most commonly used forms of the tutoring model were e-mail and WhatsApp. It was evident that WhatsApp, together with face-to-face and virtual tutoring, was one of the methods that most satisfied the students, especially WhatsApp in the second quarter of the academic year due to the special conditions. Tutorials using WhatsApp, compared to the rest of the styles, help to improve knowledge of the university and its resources, to improve the relationship with teachers, study methods, academic and professional planning, motivation and interest in study and university insertion; these results ratify those found by [12]. The immediacy of the response and the special relational link and closeness of the teachers was key for the students, a fact that facilitated the process of transition to the new model of virtual teaching improved the transition to the new virtual teaching model [20,21], and expectations towards efficacy and performance in tasks changed [22,23].

References to the accompanying counseling and support process, indicated by the students, suggest that they did not encounter an excessively stressful situation. The rapid changes experienced in such a short period of time were well-assimilated by the students thanks to the support and constant follow-up they received. The tool for the development of the virtual synchronous model (WhatsApp) is the one that is the most beneficial in terms of the adaptation process and the one that produces the most satisfaction in the students in relation to the support processes carried out by the teachers. It is relevant to highlight the similarity with some of the already reviewed studies $[12,37,38,40,41]$.

The results of this study are one of the first contributions to the role that ICT plays in the new educational model of the COVID-19 era and gives us information on which tutoring model (face-to-face, virtual, WhatsApp and e-mail) have the most beneficial impact on students. Taking into consideration the benefits of socialization, there are no tools that assess the full development of socialization (linked to processes of relationship, interaction and social contact), but they have been used to mitigate the effect of the lack of social contact [48,49]. 
It is evident that, of the four tutoring models used, WhatsApp is the one that has worked best, ahead of face-to-face academic tutoring. This fact is relatively novel and can be explained by the knowledge that students have of this communication tool and their advanced skills with this tool compared to virtual tutoring or e-mail. Synchronous communication, both by message and video call, has made WhatsApp a key tool for the development of academic orientation processes, advice and support for students. The frequent and daily use, between students and the special involvement of teachers of participating groups of students can be key elements for the explanation of these results.

This study highlights the positive effect of WhatsApp as an appropriate tool for the development and approach to tutoring in the university context. The results confirm the desirability for the use of this tool by formal and informal centers of education, in comparison to other styles. The integration of this type of tutoring in the future as a tool for the development of the tutoring process would require teacher training for effective and dynamic use, in training processes and educational orientation, which are especially relevant for tutoring [12].

The inclusion of ICT in schools and universities should promote changes and transformation of learning spaces and environments [50], as well as the creation of new teaching and learning models and guidance and tutoring based on new relationships based on intercommunication through virtual spaces and tools.

Despite these contributions, we are aware of some limitations. First, this research was transversal, so it is recommended that longitudinal designs are carried out in order to confirm the relationships indicated in the study. The same results have been obtained in other studies $[42,45]$.

The second limitation lies in the nature of the instruments that were entirely self-reported. Although the confidentiality and anonymity of the students participating was assured, the data may present some bias. Scales that use other methods for the collection of information based on observation or reporting by other participants need to be developed.

It would be interesting to amplify the tutoring models. In this study we analyzed four, justified by being the most used at the University of La Laguna (face-to-face, virtual, WhatsApp and e-mail). However, the ICT spectrum is broad and it might be of interest to explore other possibilities in order to offer alternatives to the worst valued in this study. Furthermore, future directions of the research will be focused on behavioral characteristics of the tutors, as they may have a great impact on students.

For future research it would be of interest to see how the use of ICT affects teachers. This work has shown the benefits for students and the effect on the model of advice, guidance and support to students of different styles of tutoring used at the University of La Laguna. However, the effects that WhatsApp can have on teachers is still unknown, especially considering that this tool has the benefit that communication is instantaneous, but it can also be stressful for teachers, because it does not conform to specific timetables or response times.

Author Contributions: Conceptualization, D.P.-J. and M.d.C.R.-J.; methodology, D.P.-J. and F.B.-M.; formal analysis, D.P.-J. and E.A.-M.; investigation, D.P.-J. and M.d.C.R.-J.; resources, D.P.-J. and E.A.-M.; writing-original draft preparation, D.P.-J. and F.B.-M.; writing-review, all authors; visualization, all authors; supervision, E.A.-M.; project administration, D.P.-J. and M.d.C.R.-J. All authors have read and agreed to the published version of the manuscript.

Funding: This research received no external funding.

Acknowledgments: To all the participating students and to the University of La Laguna.

Conflicts of Interest: The authors declare no conflict of interest.

\section{References}

1. García, J.L.A. La tutoría universitaria como práctica docente: Fundamentos y métodos para el desarrollo de planes de acción tutorial en la universidad. Pro Posições 2019. [CrossRef]

2. Gómez, E.L. La tutoría universitaria como relación de ayuda. Opción Rev. Cienc. Hum. Soc. 2016, 9, 1007-1024.

3. Álvarez, P.; González, M. La tutoría académica en la enseñanza superior: Una estrategia docente ante el nuevo reto de la Convergencia Europea. Rev. Electrónica Interuniv. Form. Profr 2005, 8, 1-4. 
4. Martínez-Clares, P.; Pérez-Cusó, F.J.; González-Morga, N. ¿Qué necesita el alumnado de la tutoría universitaria? Validación de un instrumento de medida a través de un análisis multivariante. Educ. XX1 2019, 22, 189-213. [CrossRef]

5. Amor, M.I.; Dios, I. La tutoría universitaria: Un espacio para la orientación personal, académica y profesional en la formación inicial del profesorado. Rev. Española Orientación Psicopedag. 2017, 28, 119-130. [CrossRef]

6. Rodríguez-Hoyos, C.; Calvo Salvador, A.; Haya Salmón, I. La tutoría académica en la educación superior. Una investigación a partir de entrevistas y grupos de discusión en la Universidad de Cantabria (España). Rev. Complut. Educ. 2015, 26, 467-481. [CrossRef]

7. Álvarez, M.; Álvarez, J. La tutoría universitaria: Del modelo actual a un modelo integral. Rev. Electrónica Interuniv. Form. Profr. 2015, 18, 125-142. [CrossRef]

8. García-Nieto, N. La función tutorial de la Universidad en el actual contexto de la Educación Superior. Rev. Interuniv. Form. Profr. 2008, 61, 21-48.

9. Lobato, C.; Ilvento, M.C. La Orientación y Tutoría universitaria: Una aproximación. Redu Rev. De Docencia Univ. 2013, 11, 17-25.

10. López-Gómez, E. El concepto y las finalidades de la tutoría universitaria. Una consulta a expertos. Rev. Española Orientación Psicopedag. 2017, 28, 61-78.

11. Pérez-Jorge, D.; Álvarez, P.; López, D. La identificación de necesidades de orientación e información del alumnado de la Facultad de Educación de la Universidad de La Laguna. Rev. Investig. Educ. 2015, 13, $271-287$.

12. Pérez-Jorge, D.; Barragán-Medero, F.; Gutiérrez-Barroso, J.; Castro-León, F. A synchronous tool for innovation and improvement of university communication, counseling and tutoring: The WhatsApp experience. Eurasia J. Math. Sci. Technol. Educ. 2018, 2737-2743. [CrossRef]

13. Sobrado, L.M. Plan de acción tutorial en los centros docentes universitarios: El rol del profesor tutor. Rev. Interuniv. Form. Profr. 2008, 61, 89-108.

14. Calderón, Y.; Herrero, D.; Andrés, C. Fortalezas y debilidades de las tutorías en educación universitaria a distancia: Resultados de talleres con tutores de ciencias exactas y naturales. Cuad. Investig. UNED 2017, 9, 179-184.

15. Klug, M.A.; Peralta, N.S. Tutorías universitarias. Percepciones de estudiantes y personal tutor sobre su uso y funcionamiento. Rev. Electrónica Educ. 2019, 23, 319-341. [CrossRef]

16. Deasy, C.; Doody, O.; Tuohy, D. An exploratory study of role transition from student to registered nurse (general, mental health and intellectual disability) in Ireland. Nurse Educ. Pract. 2011, 109-113. [CrossRef]

17. Flinkman, M.; Salanterä, S. Early career experiences and perceptions-a qualitative exploration of the turnover of young registered nurses and intention to leave the nursing profession in F inland. J. Nurs. Manag. 2015, 23, 1050-1057. [CrossRef]

18. Gardiner, I.; Sheen, J. Graduate nurse experiences of support: A review. Nurse Educ. Today 2016, 40, 7-12. [CrossRef]

19. Laschinger, H.K.S.; Cummings, G.; Leiter, M.; Wong, C.; MacPhee, M.; Ritchie, J.; Young-Ritchie, C. Starting out: A time-lagged study of new graduate nurses' transition to practice. Int. J. Nurs. Stud. 2016, 57, 82-95. [CrossRef]

20. Hu, Y.; Zhang, Y.; Shen, N.; Wu, J.; Malmedal, W.K. Stressors of newly graduated nurses in Shanghai paediatric hospital: A qualitative study. J. Nurs. Manag. 2017, 25, 184-193. [CrossRef]

21. Feng, R.F.; Tsai, Y.F. Socialisation of new graduate nurses to practising nurses. J. Clin. Nurs. 2012, 21, $2064-2071$. [CrossRef]

22. Beyers, B. Experiences of Community Service Practitioners who are Deployed at a Rural Health Facility in the Western Cape. Ph.D. Thesis, University of Western Cape, Western Cape, South Africa, 2013.

23. Zaayman, L.S. Professional Nurses' Experiences of their Community Service Placement Year at a Secondary Academic Hospital in the Western Cape. Master's Thesis, University of the Western Cape, Western Cape, South Africa, 2016.

24. Govender, S.; Brysiewicz, P.; Bhengu, B. Perceptions of newly-qualified nurses performing compulsory community service in KwaZulu-Natal. Curationis 2015, 38, 1-8. [CrossRef]

25. Delgado, J.L.C.; Rosa, L.D.L.C.M.; Serrano, M.R. Las tutorías virtuales en el proceso universitario. Opuntia Brava 2019, 11, 260-268.

26. Espinoza, E.E.; Ricaldi, M.L. El tutor en los entornos virtuales de aprendizaje. Rev. Univ. Soc. 2018, 10, $201-210$. 
27. González-Benito, A.; Mayer, A.O. Las TICs aplicadas en el desarrollo de la acción tutorial y orientadora. In 3rd Virtual International Conference on Education, Innovation and ICT; Adaya Press: Eindhoven, The Netherlands, 2019; pp. 254-263.

28. García-Valcárcel, A. La tutoría en la enseñanza universitaria y la contribución de las TIC para su mejora. Relieve 2008, 14, 1-14. [CrossRef]

29. Dodero, J.M.; Hernández, D.; Fernández, C. Desarrollo de aplicaciones Web: Evaluación de competencias mediante herramientas asíncronas. In EvalHIDA: Evaluación de Competencias con Herramientas de Interacción Dialógica Asíncronas (Foros, Blogs y Wikis); Rodríguez Gómez, G., Ed.; Universidad de Cádiz: Cadiz, Spain, 2009.

30. Godwin-Jones, R. Emerging Technologies. Blogs and Wikis: Environments for On-line Collaboration. Laguage Learn. Technol. 2003, 7, 12-16.

31. Romañá, T. Evaluar el trabajo con foros electrónicos: Propuesta de un sistema. Rev. Univ. Soc. Del Conoc. 2007, 4, 1-8.

32. Zhao, Y.; Frank, K.; Ellefson, N. Fostering meaningful teaching and learning with technology: Characteristics of effective professional development. In Mean. Learn. Using Technol. What Educ. Need Know Do; Ashburn, E., Floden, R., Eds.; Teachers College Press: New York, NY, USA, 2006; pp. 161-179.

33. Bravo-García, E.; Arbizu-Sabater, V. La creación de un contexto virtual para el aprendizaje de lenguas extranjeras mediante "hangouts". In Foro Internacional sobre Evaluación de la Calidad de la Investigación y de la Educación Superior; Ramiro Sánchez, M.T., Ramiro Sánchez, M.T., Bermúdez Sánchez, M.P., Eds.; Universidad de Ganada: Ganada, Spain, 2013; pp. 866-871.

34. Cesarina, D. La Huella Ecológica de las Redes Sociales y la Mensajería Instantánea: Propuesta de la app “Green Smartphone". 2019. Available online: https://repositorio.upct.es/bitstream/handle/10317/8013/tfmgom-hue.pdf?sequence=1 (accessed on 8 March 2020).

35. Martínez, S.L. Google Hangouts como Herramienta Pedagógica para Fortalecer las Tutorías Académicas en los Estudiantes de Segundo y Tercero de Bachillerato de la Unidad Educativa Clemente Baquerizo del Cantón Babahoyo Provincia Los Ríos. Bachelor's Thesis, UTB Babahoyo, Babahoyo, Ecuador, 2018.

36. Soto, V. Efecto de la Utilización de la Estrategia "Talleres de Éxito Académico" en Modalidad Virtual Sobre las Habilidades de Organización de Tiempo en Estudiantes de Pregrado de una Universidad Privada de la Ciudad de Barranquilla. Master's Thesis, Universidad del Norte, Barranquilla, Columbia, 2018.

37. Lantarón, B.S. Whatsapp: Su uso educativo, ventajas y desventajas. Rev. Investig. Educ. 2018, 16, 121-135.

38. Mars, M.; Scott, R.E. WhatsApp in clinical practice: A literature review. St Health T 2016, 231, 82-90. [CrossRef]

39. Román, P. Sistemas de comunicación alternativos en tutoría virtual: Los grupos de WhatsApp en la docencia universitaria. In La Alf. Multimodal: Nuevas Formas De Leer Y De Escribir En El Entorno Digit Sintesis; Camacho, A., Ed.; Universidad de Sevilla: Sevilla, Spain, 2016; pp. 121-127.

40. Rosenfeld, A.; Sina, S.; Sarne, D.; Avidov, O.; Kraus, S. A study of WhatsApp usage patterns and prediction models without message content. arXiv 2018, arXiv:1802.03393.

41. Suárez, B. El WhatsApp como herramienta de apoyo a la tutoría. Redu. Rev. De Docencia Univ. 2017, 15, $193-210$.

42. Papadakis, S.; Kalogiannakis, M.; Sifaki, E.; Vidakis, N. Access Moodle Using Smart Mobile Phones. A Case Study in a Greek University. In Interactivity, Game Creation, Design, Learning, and Innovation; Springer: Berlin/Heidelberg, Germany, 2017; pp. 376-385.

43. Papadakis, S.; Kalogiannakis, M.; Sifaki, E.; Vidakis, N. Evaluating Moodle use via Smart Mobile Phones. A case study in a Greek University. Eai Endorsed Trans. Creat. Technol. 2018, 5, 1-9. [CrossRef]

44. Wenger, E. Communities of Practice and Social Learning Systems: The Career of a Concept. In Social Learning Systems and Communities of Practice; Blackmore, C., Ed.; Springer: Berlin/Heidelberg, Germany, 2010; pp. 179-198.

45. Wenger, E.C.; Snyder, W.M. Communities of practice: The organizational frontier. Harv. Bus. Rev. 2000, 78, 139-146.

46. Peachey, N. Synchronous Online Teaching. Digit. Lang. Learn. Teach. 2017, 4, 143-155. [CrossRef]

47. Isayeva, R. How Covid-19 is Reshaping Teaching and Learning: A Perspective from Khazar University. Available online: http://owa.baku8km.khazar.org/bitstream/20.500.12323/4454/1/How\%20Covid. pdf (accessed on 15 April 2020).

48. O'Sullivan, D.; Krewer, F.; Frankl, G. Technology enhanced collaborative learning using a project-based learning management system. Int. J. Technol. Enhanc. Learn. 2017, 9, 14-36. [CrossRef] 
49. Ala-Mutka, K.; Punie, Y.; Redecker, C. Digital Competence for Lifelong Learning; Technical Note: JRC; Institute for Prospective Technological Studies (IPTS), European Commission, Joint Research Centre: Seville, Spain, 2008; Volume 48708, pp. 271-282.

50. Díaz, J.A.; Iglesias, M.; Valdés, M.L. La tutoría a distancia: Acciones del tutor en la Estrategia de Formación Doctoral en tiempos de COVID 19. Medisur 2020, 18, 478-484.

51. Cigognini, M.E.; Pettenati, M.C.; Edirisingha, P. Personal knowledge management skills in Web 2.0-based learning. In Web 2.0-based e-Learning: Applying Social Informatics for Tertiary Teaching; Lee, M.J., McLoughlin, C., Eds.; IGI Global: Pennsylvania, PA, USA, 2011; pp. 109-127.

52. Plota, D.; Karalis, T. Organization and implementation of a Flipped Classroom course in the Greek University context. Educ. J. Univ. Patras Unesco Chair 2019, 6, 53-61.

53. Raikou, N. Teacher Education at the forefront: Long-term study through the prism of University Pedagogy and Transformative Learning theory. Eur. J. Educ. Stud. 2019, 6, 88-102. [CrossRef]

54. Correa, A.D.; Pérez-Jorge, D.; Guzmán, R. El Uso de herramientas de interacción dialógica asíncrona en evaluación de competencias: Estudio de caso en el contexto universitario. Qurriculum 2011, 24, 141-171.

55. Herrera, L.; Enrique, C. Proyectos de Innovación en Tutorías en la Universidad de Granada: Análisis de los instrumentos empleados. Profesorado. Rev. Currículum y Form. Profr. 2008, 12, 1-18.

56. McMillan, J.H.; Schumacher, S. Investigación Educativa una Introducción Conceptual; Pearson Educación: London, UK, 2005.

57. Bao, W. COVID 19 y la enseñanza en línea en la educación superior: Un estudio de caso de la Universidad de Pekín. Comport. Hum. Tecnol. Emerg. 2020, 2, 113-115. [CrossRef] [PubMed]

58. Ley Orgánica 3/2018, de 5 de Diciembre, de Protección de Datos Personales y Garantía de los Derechos Digitales; Agencia Estatal Boletín Oficial del Estado: Madrid, Spain, 2018.

59. Moorhouse, B.L. Adaptations to a Face-to-Face Initial Teacher Education Course 'Forced' Online due to the COVID-19 Pandemic. J. Educ. Teach. 2020, 1-13. [CrossRef]

60. George, D.; Mallery, P. SPSS for Windows Step by Step: A simple Guide and Reference. 11.0 Update, 4th ed.; Allyn \& Bacon: Boston, MA, USA, 2003.

Publisher's Note: MDPI stays neutral with regard to jurisdictional claims in published maps and institutional affiliations.

(C) 2020 by the authors. Licensee MDPI, Basel, Switzerland. This article is an open access article distributed under the terms and conditions of the Creative Commons Attribution (CC BY) license (http://creativecommons.org/licenses/by/4.0/). 